\title{
Antimicrobial and antioxidant potentials of non-cytotoxic extracts of corticolous lichens sampled in Armenia
}

\author{
Razmik Sargsyan ${ }^{1,2}$, Arsen Gasparyan², Gohar Tadevosyan ${ }^{3}$ and Hovik Panosyan ${ }^{1 *}$ (1)
}

\begin{abstract}
Due to wide range of secondary metabolites, lichens were used from antiquity as sources of colorants, perfumes and medicaments. This research focuses on exploring the antioxidant, antimicrobial and cytotoxic activities of methanol, ethanol, acetone extracts and aqueous infusions of corticolous lichens sampled from Armenia. Methanol, ethanol and acetone extracts from all tested lichens were active against Gram-positive bacterial strains. The most effective solvent to retrieve antimicrobial compounds was methanol. Aqueous infusions of tested lichens didn't show any significant antibacterial and antifungal activity. The highest antimicrobial activity was observed for methanol extract of Ramalina sinensis. The minimum inhibitory concentration of methanol extract of Ramalina sinensis were $0.9-1.8 \mathrm{mg} \mathrm{mL}^{-1}$. Pseudevernia furfuracea demonstrated antifungal activity $(\varnothing 12 \mathrm{~mm})$. Methanol extract of Parmelia sulcata demonstrated largest 1,1-diphenyl-2-picryl-hydrazil (DPPH) radical scavenging activity (71\%). The cytotoxicity was measured on human HeLa (cervical carcinoma) cell lines using microculture tetrazolium test assay. The $\mathrm{IC}_{50}$ values estimated for methanol extracts of Peltigera praetextata, Evernia prunastri, Ramalina sinensis and Ramalina farinacea species in HeLa cell line were within 1.8-2.8 $\mathrm{mg} \mathrm{mL}^{-1}$ and considered as non-cytotoxic. Obtained results suggest that studied lichens can be prospective in biotechnologies as alternative sources of antimicrobial and antioxidant substances.
\end{abstract}

Keywords: Lichens, Crude extracts, Antimicrobial activity, Antioxidant activity, Cytotoxic activity

\section{Introduction}

About 20,000 species of lichens growing on wide variety of substrates like rocks, walls, exposed soil surfaces and as epiphytes on the bark of trees and leaves have been recorded worldwide (Ellis 2012). They are well adapted to survive in various geographical zones, from sea level to high elevations and from equator to polar regions. They are composite organisms consisting fungi as mycobiont and photosynthetic green algae and/or cyanobacteria as photobiont. Recently it was shown that besides cyanobacteria other bacteria also exist in lichen thalli and take part in mutualistic relationship (Bates et al. 2011;

\footnotetext{
*Correspondence: hpanosyan@ysu.am

${ }^{1}$ Department of Biochemistry, Microbiology and Biotechnology, Yerevan

State University, Alex Manoogian 1, 0025 Yerevan, Armenia

Full list of author information is available at the end of the article
}

Aschenbrenner et al. 2016; Pankratov et al. 2017). Due to this multiparty mutualism they adapted to survive even in extreme environments characterized by high or low temperatures, periodic desiccation, high levels of UV radiation and salinity. To withstand extreme conditions, lichens synthesized metabolites (e.g., UV screens, cryoprotectants, osmolytes) which are valuable sources to develop new biotechnologies (Suzuki et al. 2016). Ability to produce wide range of unique chemical compounds approves usage of lichens from ancient times as sources of colorants, cosmetics and remedies (Suzuki et al. 2016; Ranković 2015; Calcott et al. 2018). For example, Parmelia sulcata have been used to treat diseases of respiratory system, while Xanthoria parietina and Letharia vulpina were used against to cure jaundice and gastrointestinal disorders, respectively (Ranković et al. 2011; Crawford 2015).
Springer Open

(c) The Author(s) 2021. Open Access This article is licensed under a Creative Commons Attribution 4.0 International License, which permits use, sharing, adaptation, distribution and reproduction in any medium or format, as long as you give appropriate credit to the original author(s) and the source, provide a link to the Creative Commons licence, and indicate if changes were made. The images or other third party material in this article are included in the article's Creative Commons licence, unless indicated otherwise in a credit line to the material. If material is not included in the article's Creative Commons licence and your intended use is not permitted by statutory regulation or exceeds the permitted use, you will need to obtain permission directly from the copyright holder. To view a copy of this licence, visit http://creativecommons.org/licenses/by/4.0/. 
To date more than 800 secondary metabolites have benn identified for lichens. The continuing trends in compounds isolated from lichens approved their importance as a source of new natural products (Ranković 2015; Calcott et al. 2018; Oksanen 2006). Long time lichens were out of attention by pharmaceutical industry reasons of which were their slow-growing nature and difficulties to cultivate in laboratory conditions (Calcott et al. 2018; Yamamoto et al. 1998). For the same reason it is difficult to obtain pure lichen metabolites in needful quantity for checking out their biological activities (Ranković 2015; Calcott et al. 2018; Shrestha and Clair 2013).

Many species of lichens in form of infusions, tinctures and different extracts have been historically used in folk medicine of many countries (Crawford 2015). During the last decades, pharmaceutical potential (i.e., antifungal, antibacterial, antiviral, antitumor, cytotoxic, analgesic, antipyretic properties) of lichens sampled from different regions of the glob has been investigated (Ranković 2015; Boustie and Grube 2005; Shukla et al. 2010; Verma and Behera 2015). Despite its small territory Armenia is a crossroad for variety of rare lichen species (Gasparyan and Sipman 2013; Gasparyan et al. 2015), biodiversity and biotechnological potential of which, still remains unexplored.

Armenia is a South-Caucasian landlocked mountainous country with climate contradictions. Diverse of bio-geographical and climatic conditions, well-defined vertical zonation, as well as active tectonic processes in Armenia have contributed to the formation of ecosystems with rich biodiversity and endemic species. In this context Armenia is a crossroad also for variety of rare and still unexplored lichens' species (Gasparyan et al. 2015).

Continuous and uncontrolled use of synthetic medicaments often causes numerous side effects. This evidence forces scientists to look for new preparations of natural origin. Lichens as alternative sources can be used to search of new bioactive substances (Ranković 2015; Calcott et al. 2018). Since biotechnological potential of lichens distributed on the territory of Armenia still remains unexplored, we aimed to study of bioactivity of the aqueous and different alcoholic extracts of the corticolous lichens sampled from Armenia. In the present study antimicrobial, antioxidant and cytotoxic activities of crude methanol, ethanol and acetone extracts and aqueous infusions from $R$. sinensis, R. farinacea, F. caperata, E. prunastri, P. subrudecta, P. furfuracea, P. praetextata and $P$. sulcata were examined.

\section{Experimental}

\section{Collection and identification of lichens}

Corticolous lichen samples of Ramalina sinensis Jatta, Ramalina farinacea (L.) Ach., Flavoparmelia caperata
(L.) Hale, Evernia prunastri (L.) Ach., Punctelia subrudecta (Nyl.) Krog, Pseudevernia furfuracea (L.) Zopf, Peltigera praetextata (Sommerf.) Zopf, Parmelia sulcata Taylor were collected from the Dilijan National Park $\left(40^{\circ} 39^{\prime} 23^{\prime \prime} \mathrm{N}, 45^{\circ} 01^{\prime} 17^{\prime \prime} \mathrm{E}\right)$ and "Zikatar" Environmental Center $\left(41^{\circ} 07^{\prime} 19.02^{\prime \prime} \mathrm{N}, 44^{\circ} 55^{\prime} 32.52^{\prime \prime} \mathrm{E}\right)$, which are located in the Tavush province, Armenia. The area mostly covered by temperate deciduous forests predominating by Oriental Beech (Fagus orientalis), Hornbeam (Carpinus spp.) and Oak (Quercus spp.).

Species identification was performed by standard methods and according to the common identification guides and keys (Andreev et al. 2008; Smith 2009; Gasparyan and Sipman 2016). Voucher specimens of all lichens were deposited in the publicly available Herbarium of Yerevan State University (YSU, Yerevan, Armenia) where serial numbers of five lichens were given; $R$. sinensis Jatta (ERHM 11,071), R. farinacea (L.) Ach. (ERHM 11,072), E. prunastri (L.) Ach. (ERHM 11,073), P. furfuracea (L.) Zopf (ERHM 11,074), P. sulcata Taylor (ERHM 11,070).

\section{Preparation of lichen extracts}

Lichen thalli ( $10 \mathrm{~g}$ ) were grinded using automatic grinder, until obtaining powder-like state. Grinded thalli were drenched with methanol, ethanol and acetone separately at 10:1 solvent-to-sample ratio $(\mathrm{v} / \mathrm{w})$. The mixtures with methanol, ethanol and acetone were left for extraction for $24 \mathrm{~h}$ on magnetic stirrer, centrifuged $(15 \mathrm{~min}$, $12,000 \mathrm{rpm}$ ) and then concentrated under reduced pressure in a rotary evaporator (BOV-50 V vacuum drying oven, Biobase Meihua Trading, China) at $37^{\circ} \mathrm{C}$ temperature to dry. Extraction process was repeated three times to retrieve active compounds as much as possible. To obtain aqueous infusions the grinded lichens were dissolved in distilled water, then left for extraction for $24 \mathrm{~h}$ on magnetic stirrer under heat conditions not exceeding the boiling point. Aqueous infusions filtered through $0.22 \mu \mathrm{m}$ sterile filter (Millipore). Dried extracts were weighted and stored at $-18{ }^{\circ} \mathrm{C}$ until they were used in the tests. Dimethyl sulfoxide (DMSO) (Sigma-Aldrich) was used to prepare stock solutions. The extracts were diluted by sterile water up to $5 \%$ DMSO for the experiments.

\section{Antimicrobial activity}

The microbial strains used in this study were following: Gram-positive bacteria Bacillus subtilis WT-A1, Staphylococcus aureus MDC 5233, Gram-negative bacteria Escherichia coli VKPM-M17, Pseudomonas aeruginosa GRP3 and Salmonella typhimurium MDC 1754 and a yeast Candida albicans WT-174. Microbial strains were from microbial culture collection 
maintained by the Department of Biochemistry, Microbiology and Biotechnology, YSU.

Agar disc diffusion method was used to evaluate antimicrobial activity of lichens. The bacterial strains were inoculated in Müller-Hinton broth (MHB) and incubated overnight. Bacteria were sub-cultured in MHB liquid medium at $37{ }^{\circ} \mathrm{C}$ to $\mathrm{OD} 600=0.2$. Then $100 \mu \mathrm{L}$ of inoculum was spread on a Petri dish with Müller-Hinton agar (MHA). Yeasts were inoculated in Sabourad dextrose (SD) broth and incubated overnight. After incubation $100 \mu \mathrm{L}$ of culture was spread on SD agar. Sterilized Whatman filter paper discs $(5$ $\mathrm{mm}$ diameter) were infiltrated by $5 \mu \mathrm{L}\left(500 \mu \mathrm{g} \mathrm{mL}^{-1}\right)$ of extracts and placed on MHA or SD agar plates containing appropriate microbial strain. Diameter of inhibition zones (IZ) formed around discs after incubation at $37{ }^{\circ} \mathrm{C}$ for $24 \mathrm{~h}$ was measured. The experiments were conducted at least thrice and the average of three measurements was accepted as an index of antibacterial activity. As positive controls gentamicin $\left(10 \mu \mathrm{g} \mathrm{mL}^{-1}\right)$ (for bacteria) and nystatin $20 \mu \mathrm{g} \mathrm{mL}^{-1}$ (for yeast) were used; while $5 \%$ DMSO was used as a negative control.

Broth microdilution method was applied to determine minimum inhibitory concentration (MIC) (Wiegand et al. 2008). A series of dilutions ranging from 0.9 to $7.5 \mathrm{mg} \mathrm{mL}^{-1}$ for extracts were used in the experiment. The highest dilution of samples without visible growth after $24 \mathrm{~h}$ incubation at $37^{\circ} \mathrm{C}$ was considered as MIC. To check sterility of crude extracts all its dilutions were cultured in agar media. The minimum bactericidal/fungicidal concentration (MBC/ MFC) values was determined by sub-culturing samples from the tubes with concentrations above the MIC on new plates with MHA and SD agar for bacteria and yeast, respectively. The values obtained were the average data of experiments performed at least three time.

\section{Antioxidant activity}

Free radical scavenging method based on 1,1-diphenyl-2-picryl-hydrazil (DPPH) was used to measure antioxidant activity of lichen extracts (Molyneux 2004). The reactive solution contained $1 \mathrm{mg} \mathrm{mL}^{-1}$ ethanol extract, to which was added $0.1 \mathrm{mM}$ DPPH. The absorbance was measured spectrophotometerically $(\lambda$ $517 \mathrm{~nm}$ ). As positive control ascorbic acid was used. In negative control, the extract was replaced by ethanol. The following equation was used to evaluate radical scavenging activity $(\mathrm{RSA})$ : RSA $(\%)=\left[\left(\mathrm{A}_{0}-\mathrm{A}_{1}\right) / \mathrm{A}_{0}\right]$ $\times 100$, where $A_{0}$ absorbance of the negative control, $\mathrm{A}_{1}$ absorbance of reaction mixture or standard (Gao et al. 2000).

\section{Determination of total phenolic compounds (TPC)}

TPC was measured by the Folin-Ciocalteu method (Meda et al. 2005). $1 \mathrm{~mL}$ of methanol extracts of $1 \mathrm{mg} \mathrm{mL}^{-1}$ aliquots were mixed with $5 \mathrm{~mL}$ of Folin-Ciocalteu reagent (diluted 1:10) and $15 \mathrm{~mL}$ of $20 \%(\mathrm{w} / \mathrm{v}$ ) sodium carbonate solution. The mixture was incubated at room temperature in the dark for $1 \mathrm{~h}$ and absorbance was measured at $765 \mathrm{~nm}$. TPC was calculated as gallic acid equivalents (GAE) per $100 \mathrm{~g}$ of lichen thalli (mg GAE/100 g).

\section{Determination of total flavonoid content (TFC)}

TFC was determined by the Dowd method (Meda et al. 2005). The mixture containing $2 \mathrm{~mL}$ of methanol extracts $\left(1 \mathrm{mg} \mathrm{mL}^{-1}\right)$ and $2 \mathrm{~mL}$ of methanol solution of aluminum trichloride $(2 \%, \mathrm{v} / \mathrm{w})$ was incubated at room temperature for $30 \mathrm{~min}$. The absorbance was measured at $420 \mathrm{~nm}$. Negative control, without extract was used as a blank. TFC was determined as microgram of catechin equivalent by using an equation that was obtained from standard catechin graph. The result was expressed as $\mathrm{mg}$ of catechin equivalents per $100 \mathrm{~g}$ of lichen thalli ( $\mathrm{mg}$ CE/100 g).

\section{Cytotoxic activity}

The human HeLa (cervical carcinoma cell line) cells from the European Collection of Authenticated Cell Cultures, UK were used in experiments. The cancer cell lines were routinely maintained and cultivated in Dulbecco's Modified Eagle's medium (Sigma Aldrich, Germany) supplemented with $10 \%$ fetal bovine serum (HyClone, UK), $2 \mathrm{mM}$ L-glutamine (Sigma Aldrich, Germany), $100 \mathrm{IU}$ $\mathrm{mL}^{-1}$ penicillin (Sigma Aldrich, Germany) and $100 \mu \mathrm{g}$ $\mathrm{mL}^{-1}$ streptomycin (Sigma Aldrich, Germany). Cells were incubated in humidified atmosphere containing of $95 \%$ air and $5 \% \mathrm{CO}_{2}$ at $37^{\circ} \mathrm{C}$.

Microculture tetrazolium test (MTT) assay was used to determine the effect of extracts on cancer cell survival (Van de Loosdrecht et al. 1994). The cells were seeded at the density of $0.1 \times 10^{6} \mathrm{cell} / \mathrm{mL}^{-1}$ into 96 -well plates (Greiner, Germany). After incubation for $24 \mathrm{~h}$, different concentration of extracts obtained by diluting the stock solution $(1: 10,1: 50,1: 100,1: 200)$ were added to the cell cultures. The stock solution concentrations were for $R$. sinensis $177 \mathrm{mg} \mathrm{mL}^{-1}$, for $R$. farinacea $391 \mathrm{mg} \mathrm{mL}^{-1}$, for E. prunastri $600 \mathrm{mg} \mathrm{mL}^{-1}$, and for P. praetextata $328 \mathrm{mg}$ $\mathrm{mL}^{-1}$. The cells treated with DMSO (Sigma Aldrich, Germany) were used as vehicle control. After further incubation for $48 \mathrm{~h}$, the MTT dye (Sigma Aldrich, Germany) was added to each well ( $500 \mu \mathrm{g} \mathrm{mL}^{-1}$ final concentration) and incubated for $4 \mathrm{~h}$ at $37{ }^{\circ} \mathrm{C}$. Then the supernatant was removed and $100 \mu \mathrm{L}$ of DMSO was added. Enzymelinked immunosorbent assay (ELISA) plate reader 
(Human Reader HS, Germany) was used to measure the absorbance $(\lambda 570 \mathrm{~nm})$. Cell viability was expressed as a percentage of the negative control (cell cultures with no treatment). To reveal the cytotoxicity of the extract's doses inducing $50 \%$ inhibition of cell viability ( $\mathrm{IC}_{50}$ value) were determined.

\section{Data processing}

GraphPad Prism 5.01 (GraphPad Software, USA) was used to perform data analysis. All experiments were conducted in triplicates. Values were expressed as means \pm standard error (SE). Data were analyzed by repeated measures ANOVA. Dunn's post-hoc test was used to determine differences between groups. $\mathrm{p}<0.05$ values were considered as the statistically significant.

\section{Results}

\section{Antibacterial activity}

Results of antimicrobial activity of alcoholic extracts and aqueous infusions of tested lichens against tested bacteria and yeast are summarized in the Table 1. Diameters of IZ around used paper disks were measured to evaluate antimicrobial activity qualitatively. Aqueous infusions of all tested lichens did not demonstrate any significant antibacterial and anticandidal activity. Methanol, ethanol and acetone extracts from all tested lichens were demonstrated antibacterial activity against Gram-positive bacterial strains i.e., B. subtilis and S. aureus, while they were not able to inhibit the growth of tested Gram-negative bacteria.

The most antibacterial activity was observed for methanol extracts, which even at low concentrations were able to inhibit all tested Gram-positive bacteria. The methanol and ethanol extracts of $R$. sinensis showed the largest IZs ( $25 \mathrm{~mm}$ and $23 \mathrm{~mm}$, respectively) against the $B$. subtilis, while largest IZs (19 $\mathrm{mm}$ and $16 \mathrm{~mm}$, respectively) of the same extracts against $S$. aureus was observed in case of $F$. caperata. The same pattern is observed in case of acetone extracts of the same lichens, where largest IZs against to B. subtilis and $S$. aureus were $21 \mathrm{~mm}$ and 14 $\mathrm{mm}$, respectively.

Although all alcoholic extracts of the lichen $P$. fufuracea manifested lowest antibacterial activity, it was only lichen, methanol extract of which, demonstrated antifungal activity against $C$. albicans $(\varnothing, 12 \mathrm{~mm})$.

Since the maximum antimicrobial activity by agar disc diffusion tests was found in methanol extracts, antimicrobial activities subsequently were quantitatively evaluated by MICs and MBCs/MFCs values only for methanol extracts. MICs values were determined for each bacterium. Methanol extract from $R$. sinensis was shown relatively high antibacterial effect (MIC $0.9 \mathrm{mg} \mathrm{mL}^{-1}$ ) at the concentrations used. MIC for B. subtilis varied from 0.9 to $7.5 \mathrm{mg} \mathrm{mL}^{-1}$, while MIC for S. aureus ranged from 0.9 to more than $7.5 \mathrm{mg} \mathrm{mL}^{-1}$. MBC were determined for $B$. subtilis (in case of $R$. sinensis it was $0.9 \mathrm{mg} \mathrm{mL}^{-1}$ ) and $S$. aureus (ranged from 1.8 to $>7.5 \mu \mathrm{g} \mathrm{mL}^{-1}$ ). MFC value observed only for methanol extract of $P$. fufuracea was $>7.5 \mu \mathrm{g} \mathrm{mL}^{-1}$.

Gentamycin and nystatin were used as standard antibiotics to compare antimicrobial activities obtained for bacteria and yeast, respectively. The results confirmed that antimicrobial activities were several time higher in case of standard antibiotics. DMSO didn't show inhibitory effect on the tested organisms.

\section{Antioxidant activity}

The scavenging activity of DPPH radicals of lichen extracts is shown in Fig. 1. Methanol extracts showed a good radical scavenging activity. The highest activity showed methanol extract of $P$. sulcata with $71 \%$ activity, which was only slightly lower compared with ascorbic acid $(96 \pm 2 \%)$. Methanol extract of $P$. preatextata was also demonstrated promising scavenging activity (44\%). The methanol extract of other tested lichens showed slightly weaker DPPH radical scavenging activities $(<30 \%)$. Relatively higher scavenging activity was observed also of acetone extracts of lichens $P$. praetextata and $R$. sinensis. Ethanol and aqueous extracts were not shown significant scavenging activity of DPPH radicals. Surprisingly, aqueous extracts of $P$. praetextata, $R$. sinensis and $R$. farinacea have shown more antiradical activity then ethanol extract of the same lichens. These results were somewhat unexpected, since usually the ethanol extracts exhibiting higher radical scavenging abilities.

TPC and TFC of tested methanol extracts are shown in Table 2. Highest phenolic compounds was identified in extract of $P$. sulcata $3811 \mathrm{mg}$ GAE per $100 \mathrm{~g}$ lichen dry weight, while extract of $P$. subrudecta showed the lowest content (608 mg GAE per $100 \mathrm{~g}$ lichen dry weight). Relatively high phenolic compounds was determined also for E. prunastri (3585 mg GAE/100 g).

TFC for methanol extracts of P. sulcata, F. caperata and $R$. sinensis were 700,567 and $523 \mathrm{mg} \mathrm{CE} / 100 \mathrm{~g}$ lichen dry weight, respectively. The methanol extract of $P$. sulcata showed highest TFC among all lichen extracts, the lowest content of flavonoids was observed for P. subrudecta extracts (222 mg CE/100 g lichen dry weight). TPC and TFC of methanol extracts of studied lichen species were compared with those isolated in different part of the world (Table 2).

\section{Cytotoxic activity}

The statistically significant and dose-dependent decrease in cell viability was shown for methanol extracts of all tested lichens started from lower tested concentrations 


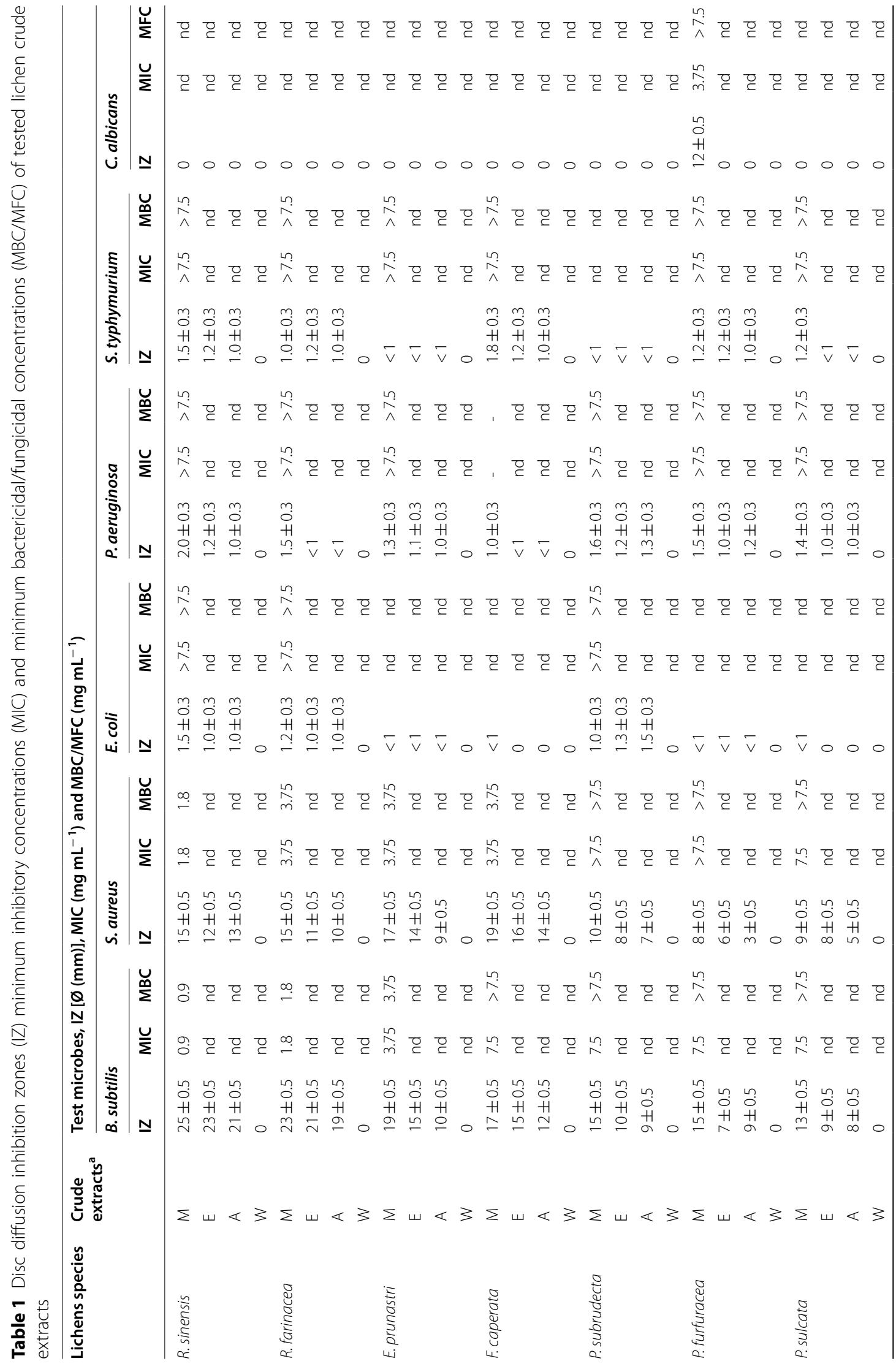




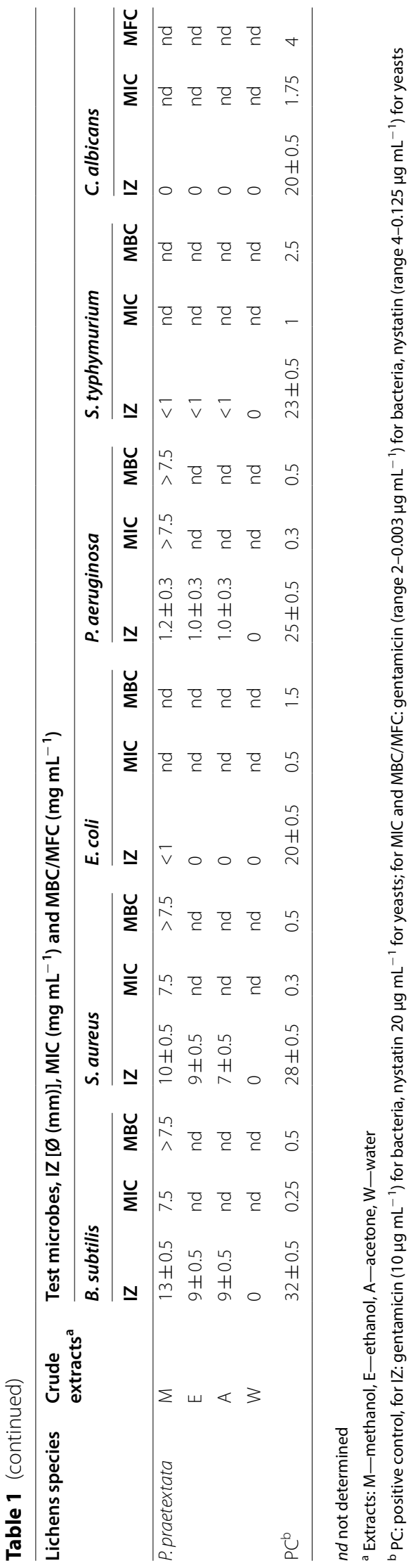




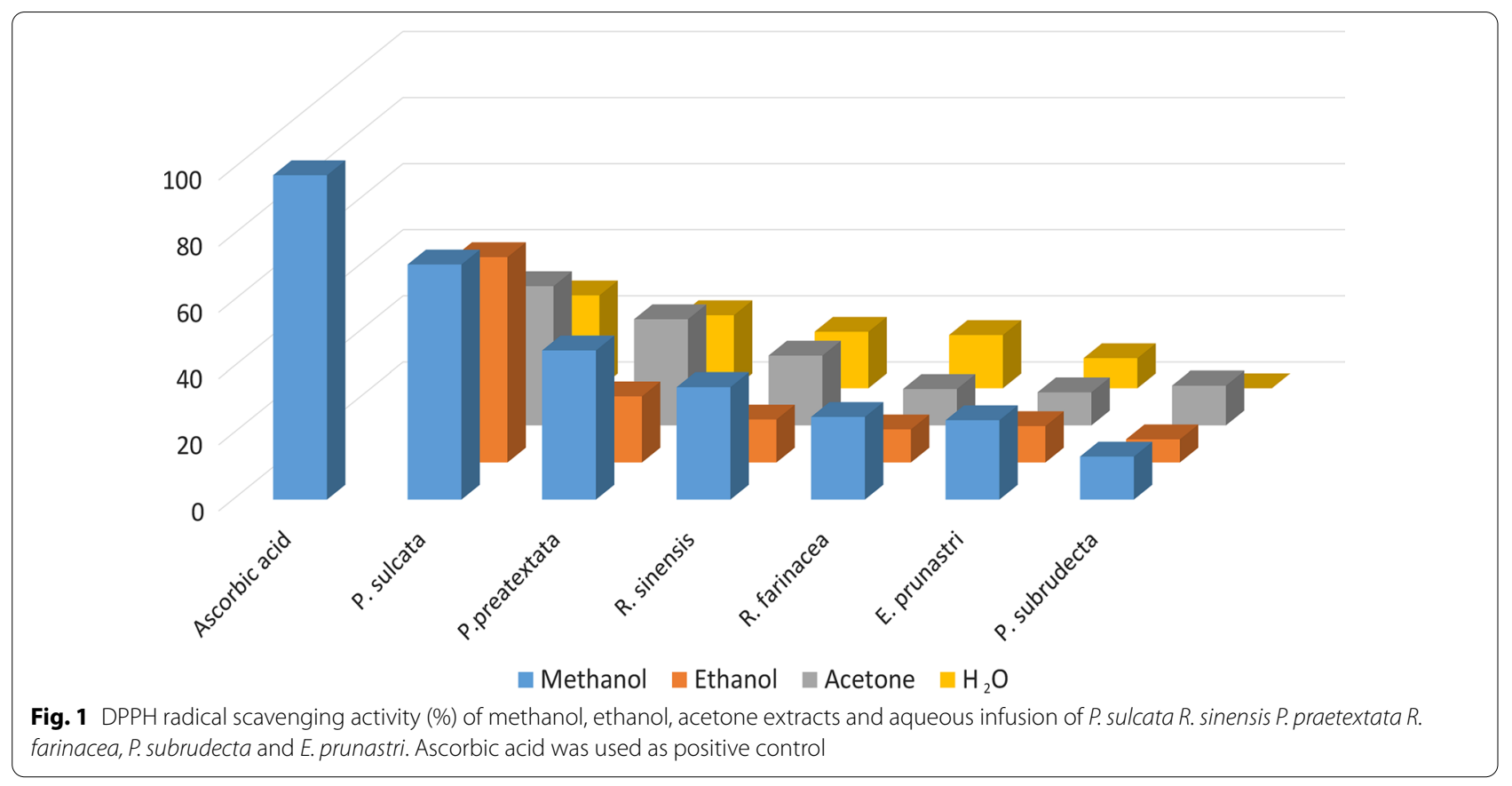

(Fig. 2). The $\mathrm{IC}_{50}$ values of $R$. sinensis and $R$. farinacea extracts were almost similar $1.8 \pm 0.1 \mathrm{mg} \mathrm{mL}^{-1}$ and $1.75 \pm 0.4 \mathrm{mg} \mathrm{mL}^{-1}$, respectively. However, at higher tested concentrations, the cytotoxic profile of mentioned extracts was different, since $10 \%$ of viability was observed at the concentration of $18 \mathrm{mg} \mathrm{mL}^{-1}$ for $R$. sinensis and $40 \mathrm{mg} \mathrm{mL}{ }^{-1}$ for $R$. farinacea extracts. The similar cytotoxic activity was shown for $P$. praetextata and $E$. prunastri extracts at all tested concentrations and the $\mathrm{IC}_{50}$ values were $2.8 \pm 0.3 \mathrm{mg} \mathrm{mL}^{-1}$ and $2.4 \pm 0.2 \mathrm{mg} \mathrm{mL}^{-1}$, respectively.

\section{Discussion}

In our experiments, aqueous infusions of all tested lichens lack of antibacterial and antifungal activities, which coincides with literature data (Kosanic and Rankovic 2014). Weak activity of aqueous infusions is probably result of insolubility or poor solubility of secondary metabolites in water (Kinoshita et al. 1994). Despite this generally accepted opinion, some researchers have also shown antimicrobial activity of some aqueous extracts of lichens. Thus, Karagouml et al. (2009) showed that aqueous extracts of $R$. farinacea and some species belonging to the genera Anaptychia, Peltigera, Umbilicaria, Xanthoria and Xanthoparmelia exhibited potent inhibition toward E. coli, B. subtilis and S. aureus. Recently it was shown aqueous extracts from Ecuadorian lichens Usnea sp. possessed antibacterial activity against B. subtilis (Matvieieva et al. 2015).
In contrast to aqueous extracts, alcoholic extracts of lichens in our experiments demonstrated relatively high antibacterial activity. The quality of the antibacterial effect depended on the species of lichen. Within tested lichen extracts only $R$. sinensis has demonstrated significant bactericidal activity against $B$. subtilis. Probably $R$. sinensis possessed activity against endospores as well. The methanol and ethanol extracts of $R$. sinensis showed the maximum antibacterial activity. The methanol extract of $F$. caperata was active against $S$. aureus.

Only static activity was observed against other tested microbes. MBC/MFC almost in all cases were higher than respective MIC values. According to the results obtained Gram-positive bacteria were more sensitive against the crude extracts of tested lichens. Such selective inhibition by extracts can be explained by composition and structural peculiarities of bacterial cell walls. Grampositive bacterial cell walls endowed with higher permeability than Gram-negative bacterial ones (Kosanic and Rankovic 2014).

Antimicrobial features of different extracts of lichen species belonging to genus Ramalina were investigated by other researchers too. Thus, ethanol extract of $R$. farinacea sampled from New Zealand showed inhibitory effect toward bacilli and some Gram-negative bacteria (Esimone and Adikwn 1999). Both tested Gram-positive and Gram-negative bacteria were sensitive against ethanol extract of $R$. farinacea sampled from Turkey (Karagouml et al. 2009). Lichen species sampled from Antarctic also demonstrated high antibacterial properties 
Table 2 TPC and TFC of methanol extracts of lichens

\begin{tabular}{|c|c|c|c|c|}
\hline \multirow[t]{2}{*}{ Lichen species } & \multicolumn{2}{|l|}{ TFC } & \multicolumn{2}{|l|}{ TPC } \\
\hline & $\begin{array}{l}\text { Present study } \\
\text { (mg CE/ } 100 \mathrm{~g} \mathrm{Dw})\end{array}$ & Literature data & $\begin{array}{l}\text { Present study } \\
\text { (mg GAE/ } 100 \mathrm{~g} \mathrm{Dw})\end{array}$ & Literature data \\
\hline P. sulcate & $700 \pm 7.1$ & $\begin{array}{l}9.6 \pm 1.09 \\
\mu \mathrm{g} \text { RuE/ mg extract }\end{array}$ & $3811 \pm 71.25$ & $\begin{array}{l}25.1 \pm 1.11 \\
\mu \mathrm{g} \text { PCE/ mg extract }{ }^{a}\end{array}$ \\
\hline E.prunastri & $373 \pm 4.2$ & $\begin{array}{l}20 \pm 3 \\
\mu \mathrm{g} Q \mathrm{QE} / \mathrm{mg} \text { extract }\end{array}$ & $3585 \pm 69.30$ & $\begin{array}{l}90 \pm 3 \\
\mu \mathrm{g} G A E / \mathrm{mg} \text { extract }\end{array}$ \\
\hline P. preatextata & $310 \pm 3.7$ & NA & $1648 \pm 72.3$ & $\begin{array}{l}109.3 \pm 0.9 \\
\mu \mathrm{g} \mathrm{CE} / \mathrm{mg} \text { extract }\end{array}$ \\
\hline F. caperata & $567 \pm 6.3$ & $\begin{array}{l}27.46 \pm 0.78 \\
\mu \mathrm{g} \text { RuE/ mg extract }\end{array}$ & $1522 \pm 67.2$ & $\begin{array}{l}90.83 \pm 0.98 \\
\mu \mathrm{g} \mathrm{GA} / \mathrm{mg} \text { extract }^{\mathrm{c}}\end{array}$ \\
\hline R. farinacea & $295 \pm 2.1$ & $\begin{array}{l}20 \pm 3 \\
\mu \mathrm{g} Q \mathrm{QE} / \mathrm{mg} \text { extract }\end{array}$ & $1128 \pm 70$ & $\begin{array}{l}75 \pm 3 \\
\mu \mathrm{g} G A E / \mathrm{mg} \text { extract }\end{array}$ \\
\hline R. sinensis & $523 \pm 5.1$ & NA & $786.5 \pm 56$ & $\begin{array}{l}14.7 \pm 0.8 \\
\mu \mathrm{g} C E / \mathrm{mg} \text { extract }\end{array}$ \\
\hline P. subrudecta & $222 \pm 2.3$ & NA & $608 \pm 42.1$ & NA \\
\hline
\end{tabular}

$D w$ dry weight, $N A$ not availbale, $Q E$ quercetin, $R u E$ rutin equivalent, $P C E$ pyrocatechol equivalent

${ }^{a}$ Data from Kosanic et al. (2010)

${ }^{b}$ Data from Aoussar et al. (2021)

' Data from Mitrovic et al. (2011)

${ }^{d}$ Data from Luo et al. (2010)

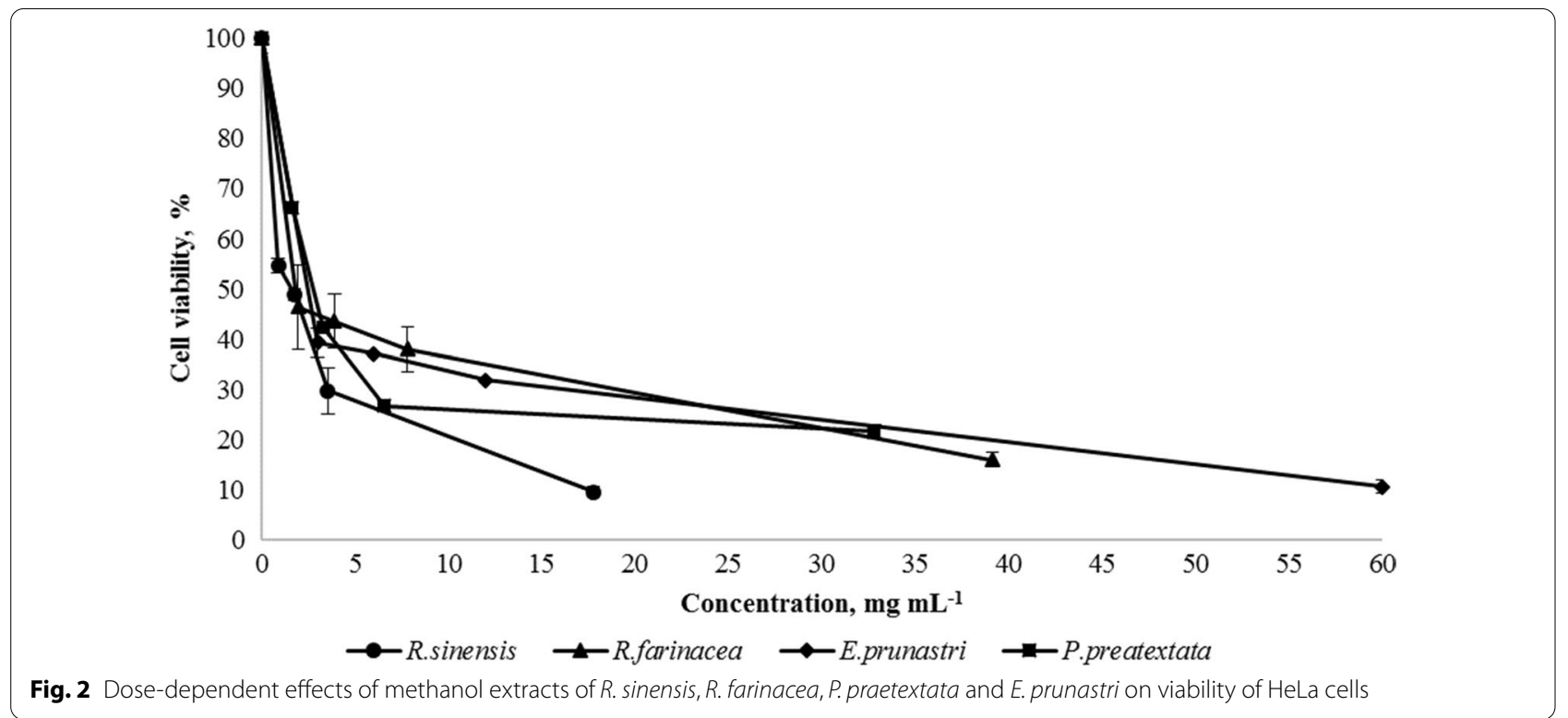

against to S. aureus and B. subtilis (Bhattarai et al. 2008; Mitrovic et al. 2011) also reported about strong inhibitory effect of methanol extracts of $P$. sulcata, F. caperata and $E$. prunastri against mainly Gram-positive bacteria. In general results obtained in this study are in agreement with literature data and confirmed high antibacterial activity of tested lichens.

Among tested lichens, Pseudevernia furfuracea was the single species demonstrating the antifungal activity.
There are some reports revealing high resistance of fungi against antimicrobial agents of lichen origin. Presumably it depends on specific composition and permeability of its cell wall (Kosanic and Rankovic 2014).

In contrast to our results, it was shown that aqueous and different polar and nonpolar extracts of many lichens also demonstrated antifungal activity. For instance, Karabuluti and Ozturk (2015) reported that some extracts of E. prunastri, P. sulcata and P. furfuracea 
demonstrated significant antifungal activity against species of genera Aspergillus, Botrytis, Fusarium, Macrophomina, Penicillium and Rhizoctonia. Using disc diffusion method Türkan et al. (2013) was shown anticandidal activity of acetone and chloroform extracts of $P$. furfuracea. Similar investigation carried out using nonpolar fractions of $P$. furfuracea exhibited significant antifungal activity especially against (Güvenç et al. 2012).

It was shown earlier that lichen thalli comprise numerous secondary metabolites with antibacterial and antifungal activity (Ranković 2015; Calcott et al. 2018; Crawford 2015; Boustie and Grube 2005; Verma and Behera 2015). The type of extracting solvent also has a decisive significance. Considering this we aimed also evaluate solvents efficiency to extract bioactive compounds from lichen thalli. As mentioned above methanol extracts demonstrated the highest antimicrobial activities. Second strongest antimicrobial activities were recorded in case of ethanol extracts, followed by acetone. Thus, we assumed that in our investigation methanol was efficient solvent to extract phenolic and/or other compounds with antimicrobial activity.

Azmir et al. (2013) evaluated the impact of solvent on the extraction process of phytochemicals. It was shown that based on the polarity of the solvent, particular compounds may be extracted (Table 3 ). Hereby we can conclude that highest activity of methanol extracts is correlating with the fact that, using methanol as a solvent derives abundant variety of bioactive compounds.

The tested lichen methanol extracts also expose relatively strong antioxidant activities against DPPH radical in vivo. The strong antioxidant activity is probably connected with the substances extracted by methanol (Azmir et al. 2013). It is distinctive that water extracts of $P$. praetextata, $R$. sinensis, $R$. farinacea and E. prunastri also derive relatively strong antioxidant activity. Moreover, the antioxidant activity of aqueous infusions of $P$. praetextata, $R$. sinensis and $R$. farinacea exceeds the activity of ethanol extracts of the same species. The scavenging activity is possible associated with secondary metabolites which are unique for that species and type of solvent. In this case, as it was mentioned the most efficient solvent was methanol.

Kumar et al. (2014) reported existence of correlation between some secondary metabolites (mainly phenols) in lichen thalli and its antioxidant properties. Correlation between phenolic and flavonoid compounds of the tested extracts and free radical scavenging activity were shown in our study too. The tested methanol extracts of $P$. sulcata exhibited the highest radical scavenging activity with the greatest amount of phenolic and flavonoid contents. However, recently some deviations from this pattern have been also shown (Odabasoglu et al. 2005). This evidence allowed to assume that antioxidant activity can be conditioned other, non-phenol components. Gülcin et al. (2002) showed strong antioxidant activity of aqueous extracts of Cetraria islandica. Stanly et al. (2011), studying some Malaysian lichens found contradiction between antioxidant activity and total phenol content. In contrast to this, methanol extracts of the lichen species $P$. sulcata, F. caperata, E. prunastri, Hypogymnia physodes and Cladonia foliacea collected from southeast of Serbia demonstrated high antioxidant activities (Mitrovic et al. 2011). In our studies, we also clearly showed that not only alcoholic solvents (which usually extracts phenolic compounds), but aqueous extracts also demonstrated antioxidant activity. Moreover, methanol extract of $P$. preatextata demonstrated relatively high DPPH radical radical scavenging activity (44\%), but TPC and TFC were low. Despite of high flavonoid and phenolic content the radical scavenging activity of methanol extract of E. prunastri was very low (Table 2; Fig. 1).

There are other reports regarding to antioxidant effect of lichens. Thus, Ranković et al. (2011) showed free radical scavenging activity ( $94.7 \%$ inhibition) for acetone extract of Lecanora atra. In this study, the highest activity was observed for methanol extract of P. sulcata with $71 \%$ activity. For comparison, it should be noted that methanol extract of another representative of the genus Parmelia (P. saxatilis) had free radical-scavenging activity with $55.3 \%$ inhibition (Kosanić et al. 2012a). To our knowledge it is the first report about high antioxidant activity observed for methanol extracts of P. sulcata.

It was established that some lichen secondary metabolites (usnic acid, lecanoric acid, lobaric acid, evernic acid, vulpinic acid and so on) have cytotoxic properties (Shrestha and Clair 2013). Cytocidal effect of mentioned metabolites displays by cell cycle arrest, apoptosis, necrosis, and inhibition of angiogenesis (Brisdelli et al. 2013).

Table 3 Example of some extracted bioactive compounds by different solvents. Adapted from Azmir et al. (2013)

\begin{tabular}{llll}
\hline Solvent & Water & Ethanol & Methanol \\
\hline Bioactive compound & Anthocyanins tannins & Tannins & Anthocyanin terpenoidssaponins \\
& Saponins terpenoids & Polyphenols flavonol & Tannins \\
& & Terpenoids alkaloids & Flavones polyphenols \\
& & Chloroform & \\
\hline
\end{tabular}


Earlier the cytotoxicity of E. prunastri extracts was analyzed in different cell lines. The weak cytotoxic effect $\left(\mathrm{IC}_{50}=120.89 \mu \mathrm{g} \mathrm{mL}{ }^{-1}\right)$ was shown for acetone extract of $E$. prunastri in FemX and LS 174 cell lines lines (Kosanić et al. 2012b). Non-cytotoxic properties of E. prunastri methanol extract was revealed on colon cancer adenocarcinoma cell line HCT-116 $\left(\mathrm{IC}_{50}=295.64 \mu \mathrm{g} \mathrm{mL}^{-1}\right.$ ) (Mitrovic et al. 2011). A crude extract of Xanthoria parietina significantly inhibited growth of Murine myeloma P3 ×63-Ag8.653 cells (Triggiani et al. 2009). Only few publications are available demonstrating anticancer activity of lichen extracts. Ari et al. (2015) reported significant anticancer effect $\left(\mathrm{IC}_{50}\right.$ values $16.5 \mu \mathrm{g} \mathrm{mL}^{-1}$ ) for methanol extract of $P$. sulcata against Human Breast cancer cell lines MDAMB-231. Viable cell number of Human colon cancer cell (HT-29) line was decreased after treatment them by acetone and methanol extracts of Lethariella zahlbruckneri (Ren et al. 2009).

In present study, the $\mathrm{IC}_{50}$ values of methanol extracts of studied lichens were in the range of $1.8-2.8 \mathrm{mg}$ $\mathrm{mL}^{-1}$. According to the American National Cancer Institute, a crude extract is considered as active for an $\mathrm{IC}_{50}<30 \mu \mathrm{g} \mathrm{mL}{ }^{-1}$ in the preliminary assay (Suffness and Pezzuto 1990). Following this criterion, the methanol extracts of studied lichen species (P. praetextata, E. prunastri, $R$. sinensis, $R$. farinacea) cannot be considered as cytotoxic. Since compounds possessing potential antimicrobial and antioxidant activities may not be useful in pharmacological preparations if they possess cytotoxic effect, the non-cytotoxic profile of extracts studied in our work proves their safety and extracts can be recommended for further studies. The obtained results stated strong antioxidant, antimicrobial activity and non-cytotoxic profile of tested lichen extracts. Lichens stand as organisms with high biotechnological potential, which was proven before by various authors, but was reported for the first time for lichens distributed on the territory of Armenia.

\section{Authors' contributions}

RS and AG carried out sampling and identification of lichens, RS prepared of extracts, carried out the antimicrobial and antioxidant activities, generated figures, tables. GT carried out cytotoxic activities and performed data analysis. HP designed and supervised the study, performed all data analysis, coordinated and edited the manuscript. All authors read and approved the final manuscript.

\section{Funding}

The work was supported by the Science Committee of RA, in the frames of the research Project No. 20AA-1 F018 and was partially supported by grants from the Norwegian Cooperation Program in Higher Education with Eurasia (CPEA LT 2016/10,095, CPEA-LT-2017/10,061) to collect samples and obtain reagents for analysis.

\section{Availability of data and materials}

Lichens are available in the Herbarium of Yerevan State University (Yerevan, Armenia). Materials and data of this study are available upon request.

\section{Declarations}

Ethics approval and consent to participate

This article does not contain any studies with human participants or animals performed by any of the authors.

\section{Consent for publication}

Not applicable.

\section{Competing interests}

The authors declare that they have no conflicts of interest.

\section{Author details}

${ }^{1}$ Department of Biochemistry, Microbiology and Biotechnology, Yerevan State University, Alex Manoogian 1, 0025 Yerevan, Armenia. ${ }^{2}$ Lichen Research and Conservation Group, Takhtajyan Institute of Botany of National Academy of Sciences of the Republic of Armenia, Hrachya Acharyan 1, 0063 Yerevan, Armenia. ${ }^{3}$ Institute of Molecular Biology, NAS of Armenia, Ezras Hasratyan 7, 0014 Yerevan, Armenia.

Received: 19 May 2021 Accepted: 21 July 2021

Published online: 29 July 2021

\section{References}

Andreev MP, Bredkina LI, Golubkova NS, Dobrysh AA, Kotlov YuV, Makarova II, Urbanavichene IN, Urbanavichus GP (2008) Handbook of the lichens of Russia 10. Agyriaceae, Anamylopsoraceae, Aphanopsidaceae, Arthrorhaphidaceae, Brigantiaeaceae, Chrysotrichaceae, Clavariaceae, Ectolechiaceae, Gomphillaceae, Gypsoplacaceae, Lecanoraceae, Lecideaceae, Mycoblastaceae, Phlyctidaceae, Physciaceae, Pilocarpaceae, Psoraceae, Ramalinaceae, Stereocaulaceae, Vezdaeaceae, Tricholomataceae. Nauka, St. Petersburg

Aoussar N, Achmit M, Es-sadeqy Y (2021) Phytochemical constituents, antioxidant and antistaphylococcal activities of Evernia prunastriemclose (L.) Achemopen Pseudevernia furfuraceaemclose (L.) Zopf. and Ramalina farinaceaemclose (L.) Ach. from Morocco. Arch Microbiol. https://doi.org/ 10.1007/s00203-021-02288-5

Ari F, Ulukaya E, Oran S, Celikler S, Ozturk S, Ozel MZ (2015) Promising anticancer activity of a lichen, Parmelia sulcata Taylor, against breast cancer cell lines and genotoxic effect on human lymphocytes. Cytotechnology 67(3):531-543. https://doi.org/10.1007/s10616-014-9713-4

Aschenbrenner IA, Cernava T, Berg G, Grube M (2016) Understanding Microbial Multi-Species Symbioses. Front Microbiol 7:180. https://doi.org/10.3389/ fmicb.2016.00180

Azmir J, Zaidul ISM, Rahman MM, Sharif KM, Mohamed A, Sahena F, Omar AKM (2013) Techniques for extraction of bioactive compounds from plant materials: a review. J Food Eng 117(4):426-436. https://doi.org/10.1016/j. jfoodeng.2013.01.014

Bates ST, Cropsey GWG, Caporaso JG, Knight R, Fierer N (2011) Bacterial communities associated with the lichen symbiosis. Appl Environ Microbiol 77:1309-1314. https://doi.org/10.1128/AEM.02257-10

Bhattarai HD, Lee JS, Paudel B, Yim JH, Hong SG (2008) Antioxidant activity of polar lichens from King George Island (Antarctica). Polar Biol 31:605-608. https://doi.org/10.1007/s00300-007-0394-8

Boustie J, Grube M (2005) Lichens-a promising source of bioactive secondary metabolites. Plant Genet Res 3(2):273-287. https://doi.org/10.1079/ PGR200572

Brisdelli F, Perilli M, Sellitri D, Piovano M, Garbarino JA, Nicoletti M, Celenza $\mathrm{G}$ (2013) Cytotoxic activity and antioxidant capacity of purified lichen metabolites: an in vitro study. Phytother Res 27:431-437. https://doi.org/ 10.1002/ptr.4739

Calcott MJ, Ackerley DF, Knight A, Keyzers RA, Owen JG (2018) Secondary metabolism in the lichen symbiosis. Chem Soc Rev 47(5):1730-1760. https://doi.org/10.1039/c7cs00431a 
Crawford SD (2015) Lichens used in traditional medicine. In: Ranković B (ed) Lichen secondary metabolites: bioactive properties and pharmaceutical potential. Springer, Heidelberg, pp 27-80

Ellis CJ (2012) Lichen epiphyte diversity: a species, community and trait-based review. Perspect Plant Ecol Evol Syst 14(2):131-152. https://doi.org/10. 1016/j.ppees.2011.10.001

Esimone CO, Adikwn MU (1999) Antimicrobial activity of the cytotoxicity of Ramalina farinacea. Fitoterapia 7:428-431. https://doi.org/10.1016/S0367326X(99)00054-4

Gao X, Björk L, Trajkovski V, Uggla M (2000) Evaluation of antioxidant activities of rosehip ethanol extracts in different test systems. J Sci Food Agric 80:2021-2027

Gasparyan A, Sipman HJM (2013) New lichen records from Armenia. Mycotaxon 123:491

Gasparyan A, Sipman HJM (2016) The epiphytic lichenized fungi in Armenia: diversity and conservation. Phytotaxa 281(1):1-68

Gasparyan A, Aptroot A, Burgaz AR, Otte V, Zakeri Z, Rico VJ, Araujo E, Crespo A, Divakar PK, Lumbsch HT (2015) First inventory of lichens and lichenicolous fungi in the Khosrov Forest State Reserve, Armenia. Fl Medit 25:105-114. https://doi.org/10.7320/FIMedit25.105

Gülçin I, Oktay M, Küfrevioğlu Öl, Aslan A (2002) Determination of antioxidant activity of lichen Cetraria islandica (L) Ach. J Ethnopharmacol 79:325-329. https://doi.org/10.1016/S0378-8741(01)00396-8

Güvenç A, Akkol EK, Süntar İ, Keleş H, Yıldız S, Çalış I (2012) Biological activities of Pseudevernia furfuracea (L.) Zopf extracts and isolation of the active compounds. J Ethnopharmacol 144:726-734. https://doi.org/10.1016/j. jep.2012.10.021

Karabuluti G, Ozturk S (2015) Antifungal activity of Everina Prunastri, Parmelia sulcata, Pseudeverina furfuracea var. furfuracea. Pak J Bot 47(4):1575-1579

Karagouml A, Doğruouml N, Zeybek Z, Aslan A (2009) Antibacterial activity of some lichen extracts. J Med Plants Res 3(12):1034-1039. https://doi.org/ 10.5897/JMPR.9000124

Kinoshita K, Matsubara H, Koyama K, Takahashi K, Yoshimura I, Yamamoto Y, Kawai KI (1994) Topics in the chemistry of lichen compounds. J Hattori Bot Lab 76:227-233. https://doi.org/10.18968/jhbl.76.0_227

Kosanic M, Rankovic B (2014) Lichen Secondary Metabolites as Potential Antibiotic Agents. In: Ranković B (ed) Lichen secondary metabolites: Bioactive properties and pharmaceutical potential. Springer, Heidelberg, pp 81-104

Kosanic M, Rankovic B, Vukojevic J (2010) Antioxidant properties of some lichen species. J Food Sci Technol 48(5):584-590. https://doi.org/10.1007/ s13197-010-0174-2

Kosanić MM, Ranković BR, Stanojković TP (2012a) Antioxidant, antimicrobial and anticancer activities of three Parmelia species. J Sci Food Agric 92(9):1909-1916. https://doi.org/10.1002/jsfa.5559

Kosanić M, Manojlović N, Janković S, Stanojković T, Ranković B (2012b) Evernia prunastri and Pseudoevernia furfuraceae lichens and their major metabolites as antioxidant, antimicrobial and anticancer agents. Food Chem Toxicol 53:112-8. https://doi.org/10.1016/j.fct.2012b.11.034

Kumar J, Dhar P, Tayade AB, Gupta D, Chaurasia OP, Upreti DK, Srivastava RB (2014) Antioxidant capacities, phenolic profile and cytotoxic effects of saxicolous lichens from trans-Himalayan cold desert of Ladakh. PLOS ONE 9(6):e98696. https://doi.org/10.1371/journal.pone.0098696

Luo H, Yamamoto Y, Liu Y, Jung JS, Kahng HY, Koh YJ, Hur JS (2010) The in vitro antioxidant properties of Chinese highland lichens. J Microbiol Biotechnol 20(11):1524-1528

Matvieieva NA, Pasichnyk LA, Zhytkevych NV, Pabón GGJ, Pidgorskyi VS (2015) Antimicrobial activity of extracts from ecuadorian lichens. Mikrobiol Z 77(3):23-27

Meda A, Lamien CE, Romito M, Millogo J, Nacoulma OG (2005) Determination of the total phenolic, flavonoid and proline contents in burkina fasan honey, as well as their radical scavenging activity. Food Chem 91:571577. https://doi.org/10.1016/j.foodchem.2004.10.006

Mitrovic T, Stamenkovic S, Cvetkovic V, Tosic S, Stankovic M, Radojevic I, Stefanovic O (2011) Antioxidant, antimicrobial and antiproliferative activities of five lichen species. Int J Mol Sci 12(8):5428-5448. https://doi.org/10. 3390/ijms12085428

Molyneux P (2004) The use of the stable free radical diphenylpicrylhydrazyl (DPPH) for estimating antioxidant activity. Songklanakarin J Sci Technol 26:211-219
Odabasoglu F, Aslan A, Cakir A, Suleyman H, Karagoz Y, Bayir Y, Halici M (2005) Antioxidant activity, reducing power phenolic content of some lichen species. Fitoterapia 76:216-219. https://doi.org/10.1016/j.fitote.2004.05. 012

Oksanen I (2006) Ecological and biotechnological aspects of lichens. Appl Microbiol Biotechnol 73(4):723-734. https://doi.org/10.1007/ s00253-006-0611-3

Pankratov TA, Kachalkin AV, Korchikov ES, Dobrovolskaya TG (2017) Microbial communities of lichens. Microbiology 86:293-309. https://doi.org/10. $1134 /$ S0026261717030134

Ranković B (ed) (2015) Lichen secondary metabolites: bioactive properties and pharmaceutical potential. Springer, Heidelberg

Ranković BR, Kosanić MM, Stanojković TP (2011) Antioxidant, antimicrobial and anticancer activity of the lichens Cladonia furcata, Lecanora atra and Lecanora muralis. BMC Complement Alternat Med 11:97. https://doi.org/ 10.1186/1472-6882-11-97

Ren MR, Hur JS, Kim JY, Park KW, Park SC, Seong CN, Seo KI (2009) Anti-proliferative effects of Lethariella zahlbruckneri extracts in human HT-29 human colon cancer cells. Food Chem Toxicol 47:2157-2162. https://doi.org/10. 1016/j.fct.2009.05.042

Shrestha G, Clair LLS (2013) Lichens: a promising source of antibiotic and anticancer drugs. Phytochem Rev 12:229-244. https://doi.org/10.1007/ s11101-013-9283-7

Shukla V, Joshi GP, Rawat MSM (2010) Lichens as a potential natural source of bioactive compounds: a review. Phytochem Rev 9:303-314. https://doi. org/10.1007/s11101-010-9189-6

Smith CW (ed) (2009) The lichens of Great Britain and Ireland. British Lichen Society, London

Stanly C, Hag Ali DM, Keng CL, Boey PL, Bhatt A (2011) Comparative evaluation of antioxidant activity and total phenolic content of selected lichen species from Malaysia. J Pharm Res 4:2824-2827

Suffness M, Pezzuto JM (1990) Assays related to cancer drug discovery. In: Hostettmann K (ed) Methods in plant biochemistry: assaysfor bioactivity, vol 6. Academic Press, London

Suzuki MT, Parrot D, Berg G, Grube M, Tomasi S (2016) Lichens as natural sources of biotechnologically relevant bacteria. Appl Microbiol Biotechnol 100(2):583-595. DOl:https://doi.org/10.1007/s00253-015-7114-z

Triggiani D, Ceccarelli D, Tiezzi A, Pisani T, Munzi S, Gaggi C, Loppi S (2009) Antiproliferative activity of lichen extracts on murine myeloma cells. Biologia 64:59-62. https://doi.org/10.2478/s11756-009-0005-y

Türkan MF, Aslan A, Yapici AN, Yapici BM, Bilgi ST (2013) Assessment of antimicrobial activity of natural leathers treated with Pseudevernia furfuracea (L.) Zopf extracts. Tekstil ve Konfeksiyon 23(2):176-180

Van de Loosdrecht AA, Beelen RHJ, Ossenkoppele G, Broekhoven MG, Langenhuijsen MMAC (1994) A tetrazolium-based colorimetric MTT assay to quantitate human monocyte mediated cytotoxicity against leukemic cells from cell lines and patients with acute myeloid leukemia. J Immunol Methods 174(1-2):311-320. https://doi.org/10.1016/0022-1759(94) 90034-5

Verma N, Behera BC (2015) Future directions in the study of pharmaceutical potential of lichens. In: Ranković B (ed) Lichen secondary metabolites: bioactive properties and pharmaceutical potential. Springer, Heidelberg, pp 179-202

Wiegand I, Hilpert K, Hancock REW (2008) Agar and broth dilution methods to determine the minimal inhibitory concentration (MIC) of antimicrobial substances. Nat Protoc 3(2):163-175. https://doi.org/10.1038/nprot.2007. 521

Yamamoto Y, Kinoshita Y, Matsubara H, Kinoshita K, Koyama K, Takahashi K, Kurokawa T, Yoshimura I (1998) Screening of biological activities and isolation of biological-active compounds from lichens. Rec Res Dev Phytochem 2:23-34

\section{Publisher's Note}

Springer Nature remains neutral with regard to jurisdictional claims in published maps and institutional affiliations. 